\title{
Pengaruh Budidaya Keramba Jaring Apung Terhadap Struktur Komunitas Perifiton pada Substrat yang Berbeda di Sekitar Dam Site Waduk PIta Koto Panjang Kampar Riau
}

\author{
The Efect Of Floating Net Cages On The Community Structure Of Periphyton On Diferent \\ Substrates On The Lacustrine Around Dam Site In Plta Koto Panjang Reservoir \\ In Kampar Regency \\ Madju Siagian \\ Dosen Fakultas Perikanan dan Ilmu Kelautan Universitas Riau, Pekanbaru \\ J1. Binawidya Km. 12.5, Panam Pekanbaru-Riau \\ Email : sagian05@yahoo.com
}

\begin{abstract}
Abstrak
Penelitian ini bertujuan mengetahui struktur komunitas perifiton pada substrat yang berbeda dan mengetahui tingkat pencemaran waduk PLTA Koto Panjang sekitar dam site dengan perifiton sebagai indikator biologis. Metode yang digunakan dengan pengukuran langsung di lapangan pada bulan November 2015 dengan pengamatan suhu, kecerahan, $\mathrm{CO}_{2}$, nitrat, fosfat, oksigen and perifiton. Hasil penelitian menunjukkan bahwa parameter kualitas yang diamati memenuhi syarat dalam mendukung hidup perifiton. Nilai indeks keanekaragaman pada substrat yang berbeda berkisar 1,117-2,24975 dimana indeks dominansi berkisar 0,24378-0,47126 dan indeks keseragaman berkisar 1-1,8. Dari nilai indeks-indeks tersebut, perairan di sekitar dam site zona lakustrin Waduk PLTA Koto Panjang telah mengalami tekanan (gangguan) dengan status tercemar ringan, tidak ada spesies yang mendominasi dan keseragaman organisme berada dalam keadaan seimbang, tidak terjadi persaingan terhadap makanan dan ruang. Dalam penelitian ini terlihat bahwa pada substrat keramba (pelampung) jenis dan jumlah individu/jenis lebih rendah dibandingkan pada substrat daun, untuk itu disarankan melihat struktur komunitas perifiton pada jaring kerambanya dikaitkan dengan keberlanjutan aktivitas budidaya ikan dalam KJA di sekitar dam site Waduk PLTA Koto Panjang. Dari hasil penelitian ini disimpulkan aktivitas budidaya ikan dalam KJA di waduk PLTA Koto Panjang di sekitar dam site mempengaruhi struktur komunitas perifiton pada masing-masing stasiun dan substrat yang berbeda.
\end{abstract}

Kata Kunci: Waduk Koto Panjang, kualitas air, perifiton, perifiton, lakustrin

\begin{abstract}
The aims of this study is to investigate periphyton community structure in the different substrates and the level pollution on the lacustrine zone around the dam site PLTA Koto Panjang reservoir and periphyton as indicators of biological. Sampling was done in November 2015 with paramaters temperature, transparancy, $\mathrm{CO}_{2}$, nitrate, phosphate, oxygen, and perifiton. The results showed that the water quality parameters quality supporting the life of periphyton. The index of diversty $\left(H^{\prime}\right)$ on different substrate $1,117-2,24975$, dominance index (C) $0,24378-0,47126$ and uniformity index (E) 1-1,8. The values of indexs above, the waters around the dam site zone lacustrine reservoir PLTA Koto Panjang have pressured (interforence) or lightly polluted, no spesies dominates and uniformity organisms are in balance, there was no competition for food and space. The results showed on the substrate cages (floating) species and number of individuals/species less than substrate leaves. This research showed that the structure of the community in the net cages associated with the sustainability of aquaculture in floating net cages around the dam site PLTA Koto Panjang reservoir. Cage culture at Koto Panjang affected perifition structure communities in different substrate.
\end{abstract}

Keywords : Reservoir Koto Panjang, water quality, periphyton, periphyton, lacustrine 
Madju Siagian : Pengaruh Budidaya Keramba Jaring Apung Terhadap Struktur Komunitas Perifiton pada Substrat yang Berbeda di Sekitar Dam Site Waduk Plta Koto Panjang Kampar Riau

\section{Pendahuluan}

Waduk merupakan genangan air yang direkayasa untuk memenuhi kebutuhan manusia seperti pertanian, air bersih, dan pembangkit listrik. Di Indonesia, waduk juga dapat digunakan sebagai sarana rekreasi dan juga budidaya ikan. Adanya sinergitas ini membuat nilai ekonomi waduk sebenarnya dapat lebih termaksimalkan. Khusus untuk budidaya ikan, hampir semua waduk yang ada di Indonesia dimanfaatkan untuk kegiatan ini dan cenderung meningkat dari tahun ke tahun. Perkembangan KJA ini membawa sisi positif kepada para nelayan, namun disisi lain adanya perubahan sistem ekologis di kolom air seperti pencemaran akibat buangan limbah pakan.

Salah satu waduk yang dimanfaatkan untuk budidaya adalah Waduk PLTA Koto Panjang di Provinsi Riau. Waduk ini mempunyai luasnya 12.400 ha, merupakan salah satu sumberdaya alam perairan yang sangat strategis dan penting bagi perkembangan perekonomian masyarakat setempat. Waduk PLTA Koto Panjang dibangun pada tahun 1992 dan selesai pada tahun 1997. Setelah waduk tersebut dibangun kegiatan masyarakat yang menonjol di badan perairan Waduk PLTA Koto Panjang adalah pemeliharaan ikan sistem Keramba Jaring Apung (KJA) yang terkonsentrasi sekitar Dam Site waduk tersebut. Pada tahun 2003 jumlah KJA yang beroperasi di sekitar Dam Site sebanyak 196 petak menurut Nur (2006). Menurut Siagian (2010) pada tahun 2006 jumlah KJA sebanyak 513 petak dan pada tahun 2009 jumlah KJA sebanyak 900 petak. Selanjutnya menurut Simarmata et al., (2013) jumlah KJA sebanyak 1.100 petak. Dari data di atas dapat dikemukakan, bahwa peningkatan jumlah KJA di sekitar Dam Site waduk ini berkembang pesat.
Peningkatan jumlah KJA ini dapat mempengaruhi kualitas air waduk akibat adanya beban limbah berupa sisa pakan, feses, dan skresi lainnya. Siagian (2014) dalam penelitiannya mengemukakan, bahwa waduk PLTA Koto Panjang zona lakustrin sekitar Dam Site termasuk pada kriteria tercemar ringan. Kondisi perairan yang demikan dapat mempeharuhi jasad-jasad hidup, salah satu diantaranya adalah perifiton yang merupakan organisme mikro yang dapat menempel pada substrat dan dapat menggambarkan kondisi suatu perairan. Untuk melihat hal tersebut, maka dilakukan penelitian di derah inlet dari waduk tersebut. Hal ini untuk melihat bagaimana kondisi fisis perairan dan juga perifition dalam membangun sistem biologi disekitar inlet. Penelitian ini juga akan menekankan bagaimana pentingnya pengelolaan waduk berdasarkan parameter yang ada sehingga nantinya dapat dikelola dengan baik terutama dalam hal pakan dan jumlah fasilitas budidaya. Hasil penelitian ini juga dapat diaplikasikan ke waduk lainnya yang mempunyai KJA.

\section{Bahan dan Metode}

Penelitian ini dilaksanakan pada bulan Juni sampai November 2015 di waduk PLTA Koto Panjang, Kabupaten Kampar, Propinsi Riau. Lokasi dan stasiun pengambilan sampel disajikan pada Gambar 1. Penelitian ini dilaksanakan dengan menggunakan metode deskriptif bersifat noneksperimental, yaitu penelitian yang dilakukan di lapangan dan analisa sampel ada yang dilakukan di lapangan dan di laboratorium. 


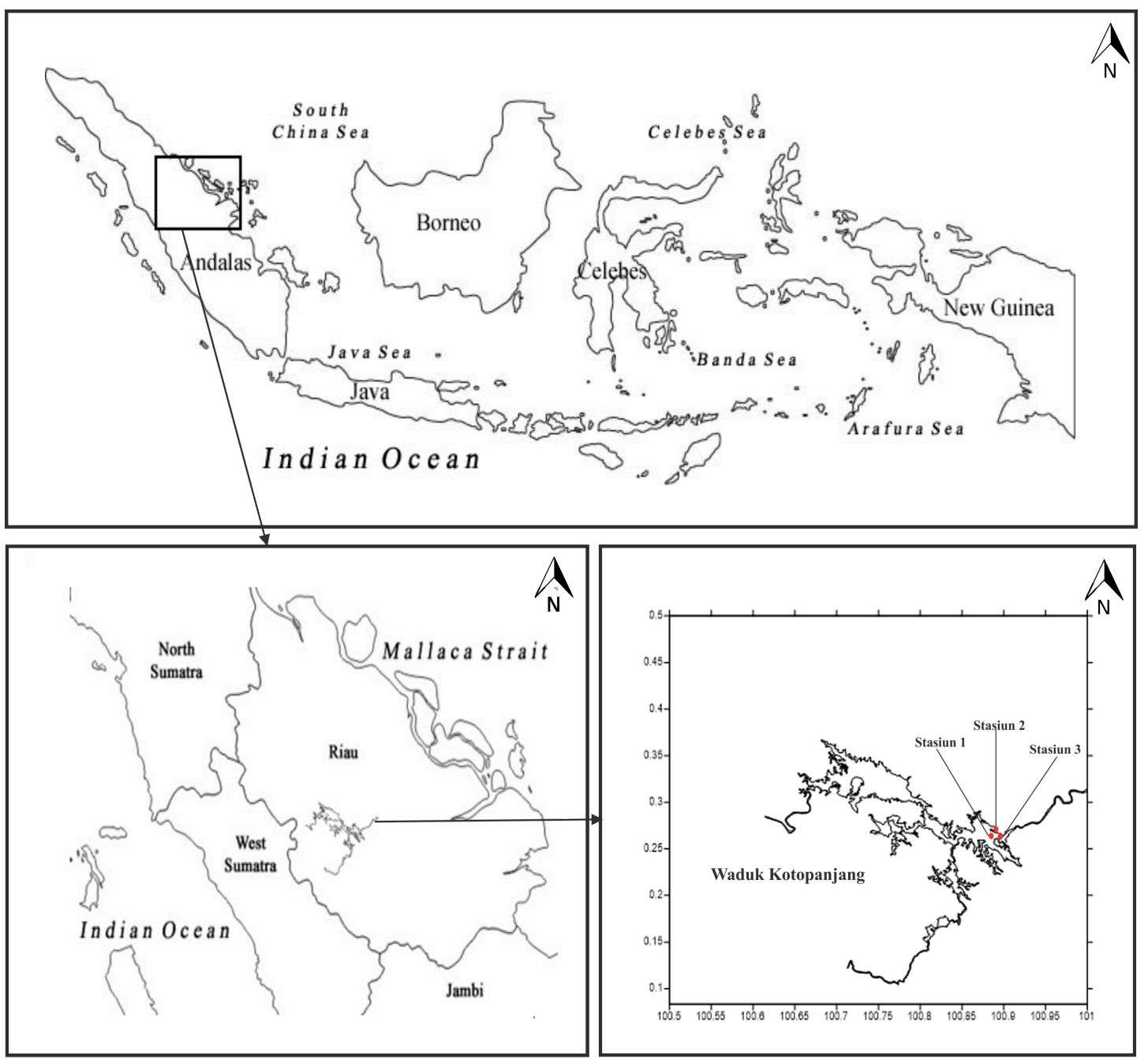

Gambar 1. Peta stasiun penelitian di waduk PLTA Koto Panjang

Figure 1. Map of research station in Koto Panjang Reservoir

Komponen-komponen yang dilihat adalah kualitas fisika, kimia dan biologis (perifiton). Parameter kualitas air yang diamati di lapangan adalah suhu, kecerahan, oksigen, $\mathrm{pH}$, dan karbon dioksida, sedangkan konsentrasi nitrat, fosfat dianalisa di Laboratorium Produktivitas Perairan, Fakultas Perikanan dan Ilmu Kelautan, Universitas Riau. Parameter biologis yaitu perifiton dianalisa di laboratorium yang sama dengan tempat analisa nitrat dan fosfat. Sampling dilakukan secara horizontal ditentukan pada tiga stasiun masing-masing tiga sub stasiun untuk kualitas air diambil pada lapisan permukaan. Penelitian ini dilakukan di lapangan dan di laboratorium yang berlangsung selama 5 bulan. Pengambilan sampel air dan perifiton dilakukan setiap 2 minggu mulai bulan Juli sampai bulan September 2015. Jadi pengambilan sampel air dan perifiton di lapangan dilakukan sebanyak empat kali ulangan. Parameter kualitas air (fisik, kimia) dan biologis yang diamayi disajikan pada Tabel 1 . 
Madju Siagian : Pengaruh Budidaya Keramba Jaring Apung Terhadap Struktur Komunitas Perifiton pada Substrat yang Berbeda di Sekitar Dam Site Waduk Plta Koto Panjang Kampar Riau

Tabel 1. Parameter Kualitas Air yang Diukur, Metode, Tempat Analisis Sampel Selama Penelitian ( APHA, 1995.)

Tabel 1. Water Quality Parameters, Methode and Analysis Sample During Research

\begin{tabular}{llcll}
\hline Nomor & \multicolumn{1}{c}{ Parameter } & Satuan & \multicolumn{1}{c}{ Metode } & Tempat Analisa Sampel \\
\hline $\mathrm{A}$ & Fisika & & & \\
1 & Suhu & ${ }^{\circ} \mathrm{C}$ & Pemuaian & Lapangan \\
2 & Kecerahan & $\mathrm{cm}$ & $\begin{array}{l}\text { Pemantulan } \\
\text { Lapangan }\end{array}$ \\
3 & Kedalaman & $\mathrm{m}$ & Grafimetrik & Lapangan \\
$\mathrm{B}$ & Kimia & & & \\
1 & $\mathrm{pH}$ & - & Perubahan warna & Lapangan \\
2 & Oksigen Terlarut & $\mathrm{mg} / \mathrm{L}$ & $\begin{array}{l}\text { Titrimetrik } \\
\text { Lapangan }\end{array}$ \\
& & & /Winkler & \\
3 & Karbondioksida & $\mathrm{mg} / \mathrm{L}$ & Titrimetrik & Lapangan \\
& Bebas & & & \\
4 & Nitrat & $\mathrm{mg} / \mathrm{L}$ & Brucine & Laboratorium \\
5 & Fosfat & $\mathrm{mg} / \mathrm{L}$ & SnCl2 & Laboratorim \\
$\mathrm{C}$ & Biologi & & & \\
& perifiton & $\mathrm{sel} / \mathrm{cm} 2$ & Identifikasi & Laboratorium \\
\hline
\end{tabular}

\section{Hasil dan Pembahasan}

\section{Kualitas air}

Hasil pengukuran kualitas air di Waduk PLTA Koto Panjang selama penelitian disajikan pada Tabel 2. Dari Tabel ini dapat dilihat kecerahan berkisar dari $134 \mathrm{~cm}-136 \mathrm{~cm}$, suhu berkisar $28,2^{\circ} \mathrm{C}-29,2^{\circ} \mathrm{C}$, oksigen berkisar $3,7 \mathrm{mg} / \mathrm{L}-3,9$ $\mathrm{mg} / \mathrm{L}, \mathrm{pH}$ 6,3-6,6 karbon dioksida berkisar 4,01 $\mathrm{mg} / \mathrm{L}-4,3 \mathrm{mg} / \mathrm{L}$, nitrat berkisar $0,04 \mathrm{mg} / \mathrm{L}-0,13$ $\mathrm{mg} / \mathrm{L}$ dan fosfat berkisar $0,06 \mathrm{mg} / \mathrm{L}-0,18 \mathrm{mg} / \mathrm{L}$.

Tabel 2. Nilai Rata-rata Parameter Kualitas Air pada Masing-masing Stasiun Selama Penelitian Table 2. Average Water Quality per Station During Research Period

\begin{tabular}{cccccccc}
\hline Stasiun & \multicolumn{7}{c}{ Parameter Fisika - Kimia } \\
\cline { 2 - 7 } & $\begin{array}{c}\text { Kecerahan } \\
(\mathrm{cm})\end{array}$ & $\begin{array}{c}\text { Suhu } \\
\left({ }^{\circ} \mathrm{C}\right)\end{array}$ & $\mathrm{pH}$ & $\begin{array}{c}\text { Oksigen } \\
(\mathrm{mg} / \mathrm{L})\end{array}$ & $\begin{array}{c}\mathrm{CO}_{2} \\
(\mathrm{mg} / \mathrm{L})\end{array}$ & $\begin{array}{c}\text { Nitrat } \\
(\mathrm{mg} / \mathrm{L})\end{array}$ & $\begin{array}{c}\text { Fosfat } \\
(\mathrm{mg} / \mathrm{L})\end{array}$ \\
\hline 1 & 135 & 28,2 & 6,3 & 3,9 & 4,01 & 0,04 & 0,06 \\
2 & 134 & 28,4 & 6,5 & 3,9 & 4,13 & 0,13 & 0,18 \\
3 & 136 & 29,2 & 6,6 & 3,7 & 4,3 & 0,09 & 0,13 \\
\hline
\end{tabular}

Dari Tabel 2 dapat dilihat Nilai kecerahan rata-rata yang ditemukan dalam penelitian ini antar satu stasiun dengan satasiun ainnya yatu $135-136 \mathrm{~cm}$. Kecerahan yang demikian cukup tinggi dan cukup baik untuk kehidupan organisme akuatik sesuai dengan pendapat Suhadi et al., (1989) yang mengemukakan, bahwa kecerahan minimal adalah $45 \mathrm{~cm}$ dan nilai kecerahan masih di atas $60-90 \mathrm{~cm}$ yang dikemukakan oleh Allaerts dan Santika (1984), dianggap cukup baik untuk menunjang kehidupan organisme perairan.
Suhu air rata-rata berkisar dari 28,2-29, $2^{\circ} \mathrm{C}$. Dari kisaran suhu ini dapat dikatakan bahwa perairan Waduk PLTA Koto Panjang sekitar dam site masih layak untuk kehidupan organisme perairan. Hal ini sesuai dengan pendapat Cholic (1986) kisaran suhu yang baik untuk organisme perairan termasuk ikan berada pada kisaran $25^{\circ} \mathrm{C}-32^{\circ} \mathrm{C}$, maka kondisi suhu yang diperoleh dalam penelitian ini masih cocok bagi hidup dan kehidupan organisme perairan. Nilai $\mathrm{pH}$ rata-rata menunjukkan nilai $\mathrm{pH}$ berkisar dari 6,3-6,6. Berkitan dengan $\mathrm{pH}$ 
Pillay (1992) secara umum untuk ikan berkisar 5-9, Parker (2002) mengemukakan 4-6 pertumbuhan ikan lambat dan disarankan $\mathrm{pH}$ yang baik untuk pertumbuhan dan produksi ikan adalah 6,5-9. Jika $\mathrm{pH}$ perairan dalam penelitian ini dibandingkan dengan pendapat-pendapat di atas dapat disimpulkan bahwa kisaran $\mathrm{pH}$ yang terjadi di waduk PLTA zona lakustrin sekitar dam site masih berada dalam kisaran yang diinginkan. Konsentrasi oksigen rata-rata berkisar dari 3,7-3,9 mg/L. Ada beberapa pendapat mengenai konsentrasi oksigen untuk kebutuhan organisme perairan Schmittow (1991) menyarankan batas minimal $3 \mathrm{mg} / \mathrm{L}$. Pillay (1992) menyarankan perairan yang mengandung oksigen $5 \mathrm{mg} / \mathrm{L}$, Parker (2002) mengemukakan konsentrasi oksigen $0,3-1 \mathrm{mg} / \mathrm{l}$ merupakan konsentrasi yang mematikan bagi ikan, $1,0-5 \mathrm{mg} / \mathrm{L}$ ikan dapat hidup tetapi pertumbuhannya lambat apabila terjadi dalam waktu yang lama dan konsentrasi oksigen $>5$ $\mathrm{mg} / \mathrm{L}$ merupakan yang disarankan untuk pertumbuhan dan produksi yang baik. Apabila konsentrasi oksigen yang diperoleh dalam penelitian ini dengan pendapat-pendapat di atas maka kawasan waduk PLTA Koto Panjang zona lakustrin sekitar dam site masih baik untuk kehidupan organisme perairan. Rata-rata kandungan karbondioksida bebas berkisar dari 4,01 mg/L-4,3 mg/L. Nilai ini masih rendah jika dibandingkan dengan pendapat Asmaswi (1980) yang menyarankan kadar $\mathrm{CO}_{2}$ yang dikehendaki oleh organisme akuatik tidak lebih dari $12 \mathrm{mg} / \mathrm{L}$ dan terendah $2 \mathrm{mg} / \mathrm{L}$. Hal yang sama dikemukakan Pillay (1992) dalam Parker (2002) menyarankan dalam pemeliharaan ikan kadar $\mathrm{CO}_{2}$ di atas tersebut hingga $60 \mathrm{mg} / \mathrm{L}$ dapat ditoleransi ikan apabila kadar oksigennya tinggi. Jadi karbondioksida yang ada di lokasi penelitian ini belum membahayakan atau masih dapat mendukung kehidupan organisme yang ada.

Kandungan nitrat menunjukkan bahwa kandungan nitrat rata-rata berkisar dari 0,04 $\mathrm{mg} / \mathrm{L}-0,13 \mathrm{mg} / \mathrm{L}$. Menurut Goldman dan Home (1982) kesuburan perairan berdasarkan konsentrasi nitrat yaitu kurang subur atau oligotrofik (konsentrasi nitrat 0,0-0,1 mg/L), kesuburan perairan sedang atau mesotrofik (konsentrasi nitrat 0,1-0,2 mg/L) dan kesuburan perairan tinggi atau eutrofik (konsentrasi nitrat $>$ 0,2 $\mathrm{mg} / \mathrm{L})$. Jika konsentrasi nitrat dalam penelitian ini yang berkisar dari $0,04-0,13 \mathrm{mg} / \mathrm{L}$ dibandingkan dengan pendapat di atas maka tingkat kesuburan waduk PLTA Koto Panjang sekitar dam site termasuk pada kategori kesuburan sedang. Menurut Pescod !973) kadar nitrat yang baik untuk petumbuhan perifiton adalah $<0,2 \mathrm{mg} / \mathrm{L}$. Jadi kadar nitrat dalam penelitian ini baik untuk pertubuhan perifiton. Kadar fosfat rata-rata berkisar $0,06 \mathrm{mg} / \mathrm{L}-0,18$ $\mathrm{mg} / \mathrm{L}$. Sehubungan dengan konsentrasi fosfat dikaitkan dengan tingkat kesuburan perairan Goldman dan Home (1982) mengelompokkan kesuburan perairan atas lima tingkatan yaitu kesuburan rendah atau ultra oligotrofik (kadar fosfat $0,000-0,020 \mathrm{mg} / \mathrm{L}$ ), kesuburan cukup atau oligotrofik (kadar fosfat 0,021-0,050 mg/L), kesuburan sedang atau mesotrofik (kadar fosfat 0,051-0,100 mg/L), kesuburan baik sekali atau eutrofik (kadar fosfat $0,101-0,200 \mathrm{mg} / \mathrm{L}$ ) dan perairan terlalu subur atau hipertrofik (kadar fosfat .0,200 mg/L). Kadar fosfat dalam penelitian ini berkisar $0,06 \mathrm{mg} / \mathrm{L}-0,18 \mathrm{mg} / \mathrm{L}$ dibandingkan dengan pendapat di atas maka perairan Waduk PLTA Koto Panjang Sekitar dam site tergolong pada perairan yang tingkat kesuburan baik atau eutrofik. Sehubungan dengan kandungann fosfat Suharsanto (2003) menyatakan kisaran fosfat yang baik untuk pertumbuhna perifiton adalah 0,01-1 mg/L, jadi kadar fosfat dalam penelitian ini baik untuk pertumbuhan perifiton.

\section{Jenis dan Kelimpahan Perifiton}

Jenis dan kelimpahan rata-rata perifiton pada substrat yang berbeda pada masing-masing Stasiun di sekitar dam site Waduk PLTA Koto Panjang disajikan pada Tabel 3. 
Madju Siagian : Pengaruh Budidaya Keramba Jaring Apung Terhadap Struktur Komunitas Perifiton pada Substrat yang Berbeda di Sekitar Dam Site Waduk Plta Koto Panjang Kampar Riau

Tabel 3. Jenis dan Kelimpahan Rata-rata $\left(\mathrm{sel} / \mathrm{cm}^{2}\right)$ Perifiton pada Substrat dan Stasiun yang Berbeda di Sekitar Dam Site Waduk PLTA Koto Panjang Selama Penelitian

Table3. Komposition and Periphyton Abundance $\left(\mathrm{sel} / \mathrm{cm}^{2}\right)$ per Station and Subdtrat in Koto Panjang Reservoir During Research Period

\begin{tabular}{cccccccc}
\hline No & Jenis & \multicolumn{2}{c}{ Substrat } & Keramba ( Pelampung) & \multicolumn{3}{c}{ Substrat Daun } \\
\cline { 3 - 8 } & & Stasiun 1 & Stasiun 2 & Stasiun 3 & Stasiun 1 & Stasiun 2 & Stasiun 3 \\
\hline 1 & Diatomeae sp & 2.168 & 2.376 & 3.002 & 5.713 & 2.554 & 1.209 \\
2 & Nitzshia sp & 2.001 & 2.168 & 2.501 & 9.634 & 3.667 & 1.960 \\
3 & Cyclotella sp & 833 & 1.001 & & 8.593 & & \\
4 & Fragilaria sp & & & 1.723 & & 3.671 & 585 \\
5 & Coconeis sp & & & & 1.668 & 1.293 & \\
6 & Gyrosigma sp & & & & 2.377 & 1.751 & \\
7 & Melosira sp & & & & 5.045 & 1,557 & 751 \\
8 & Navicula sp & & & & 4.442 & \\
\hline
\end{tabular}

Tabel 3 menunjukkan, bahwa jenis perifiton lebih banyak ditemukan pada substrat daun (8 jenis) dibandingkan pada KJA (4 Jenis). Hal ini dapat disebabkan karena adanya perbedaan substrat yaitu dalam KJA substrat yang diambil pada pelampung keramba yang merupakan benda mati, sedangkan substrat daun merupakan substrat alami. Keberadaan perifiton di perairan sangat ditentukan oleh kemantapan substrat. Substrat benda hidup atau organisme hidup sering bersifat sementara, sedangkan substrat benda mati sifatnya stabil. Pada penelitian ini ditemukan jenis perifiton pada substrat daun lebih banyak. Hal ini disebabkan pada substrat alami jenis yang hidup secara alami akan lebih mudah ditemukan sehingga jenis perifiton yang ditemukan pada substrat alami lebih banyak dibandingkan pada substrat buatan. Ini sesuai dengan pendapat Ruttner (1974) dalam Muharram (2006) yang mengemukakan keterkaitan jenis perifiton dengan substrat.

Kelimpahan rata-rata perifiton pada substrat yang berbeda dan stasiun yang berbeda yang ditemukan di sekitar dam site Waduk PLTA Koto Panjang selama penelitian dapat dilihat pada Tabel 4.

Tabel 4. Total Kelimpahan Rata-rata Perifiton pada Substrat dan Stasiun yang Berbeda di Sekitar Dam Site Waduk PLTA Koto Panjang Selama Penelitian

Table 4. Average Periphyton Abundance $\left(\mathrm{sel} / \mathrm{cm}^{2}\right)$ per Station and Substrat in Koto Panjang Reservoir During Research Period

\begin{tabular}{|c|c|c|}
\hline \multirow[t]{2}{*}{ Stasiun Pengambilan Sampel } & \multicolumn{2}{|c|}{ Total Kelimpahan Rata-rata $\left(\mathrm{sel} / \mathrm{cm}^{2}\right)$} \\
\hline & Substrat Keramba (Pelampung) & Substrat Daun \\
\hline 1 (Sedang KJA) & 5.002 & 33.030 \\
\hline 2 (Padat KJA) & 5.544 & 18.935 \\
\hline 3 (Jarang KJA) & 7.226 & 4.505 \\
\hline
\end{tabular}

Tabel 4, menunjukkan bahwa kelimpahan rata-rata perifiton selama penelitian berkisar $4.505-33.030 \mathrm{sel} / \mathrm{L}$. Selanjutnya dapat dilihat bahwa semakin padat KJA pada substrat keramba lebih rendah dibandingkan yang jarang KJA tetapi lebih tinggi dibandingkan dengan yang sedang KJA. Hal ini disebabkan kecerahannya yang berbeda sehingga intensitas cahaya matahari semakin menurun sehingga jumlah perifiton semakin menurun. Hal ini sesuai dengan pendapat Barus (2004) yang mengemukakan jumlah perifiton yang ditemukan semakin meningkat dengan meningkatnya kecerahan. Terjadinya perbedaan kecerahan ini kerena pada stasiun ini terletak pada lokasi yang pada lokasi yang padat KJA. yang menghasilkan sisa-sisa pakan menyebabkan bahan-bahan organik pada perrairan yang menyebabkan kekeruhan sehingga kecerahan semakin menurun. Hal ini menyebabkan intensitas cahaya matahari yang masuk ke perairan semakin menurun menyebabkan kelimpahan 
perifiton semakin menurun. Hal ini sejalan dengan pendapat Boyd (1982) yang mengemukakan bahwa kecerahan suatu perairan ditentukan oleh adanya kandungan bahan organik. Selanjutnya Nybakken (1992) menyatakan, bahan organik menyebabkan penurunan kecerahan sehingga penetrasi cahaya matahari semakin menurun akan mempengaruhi proses fotosintesis yang mempengaruhi kelimpahan.

Tabel 4, menunjukkan kelimpahan perifiton pada substrat keramba (pelampung) berkisar dari $5.002 \mathrm{sel} / \mathrm{cm}^{2}-7.226 \mathrm{sel} / \mathrm{cm}^{2}$ sedangkan pada sumbtrat daun berkisar dari $4.505 \mathrm{sel} / \mathrm{cm}^{2}-33.030$ sel/cm2. Adanya perbedaan kelimpahan perifiton ini disebabkan substrat daun kemantapannya lebih baik karena alami sifatnya sedangkan substrat keramba (pelampung) merupakan substrat buatan. Sehubungan dengan perkembangan perifiton menuju kemantapan komunitas sangat ditentukan oleh kemantapan substrat. Substrat dari benda hidup sering bersifat sementara, karena adanya proses pertumbuhan dan kematian, sedangkan pada substrat benda mati akan lebih bersifat stabil (Ruttner 1974 dalam Muharram 2006). Selanjutnya Harlin (1980) dalam Simanjuntak (2013), pada substrat alami spesies perifiton yang hidup secara alami lebih mudah ditemukan dan jenisnisnya lebih banyak. Jika pendapat tersebut dibandingkan dengan jenis dan kelimpahan perifiton pada substrat daun lebih banyak dibandingkan pada substrat keramba.

Rendahnya kelimpahan perifiton pada substrat keramba dibandingkkan pada substrat daun dapat disebabkan pada substrat keramba (pelampung) sifatnya terlindung sehingga cahaya matahari dipantulkan oleh substratnya sehingga cahaya matahari yang bisa dimanfaatkan oleh perifiton semakin berkurang, sedangkan pada substrat daun pada semua stasiun sifatnya terbuka sehingga intensitas cahaya matahari yang masuk lebih banyak. Hal ini menyebabkan laju fotosintesis perifiton pada substrat keramba lebih rendah dan jenisnya lebih sedikit dibandingkan pada substrat daun jenisnya lebih banyak intesitas cahaya lebih banyak sehingga laju photosintesis lebih tinggi sehingga kelimpahannya lebih banyak dibandingkan pada substrat keramba.

\section{Struktur Komunitas Perifiton}

Untuk melihat struktur komunitas perifiton di sekitar Dam Site waduk PLTA Koto Panjang dalam penelitian dapat dilihat dari indeks keanekaragaman jenis, indeks dominasi Jenis dan dari indeks keseragaman jenis. Nilai ratarata dari ketiga indeks yang diamati pada setiap stasiun dan substrat yang berbeda ditampilkan pada Tabel 5 dan Tabel 6 .

Tabel 5. Nilai Rata-rata Indeks Keanekaragaman (H'), Dominansi (C) dan Keseragaman Jenis (E) Perifiton pada Substrat Daun Setiap Stasiun Selama Penelitian

Table 5. Average Diversity (H'), Dominance (C) and Uniformity Index (E) on The Leave Substrate in Koto Panjang Reservoir During Research Period

\begin{tabular}{cccc}
\hline Stasiun & \multicolumn{2}{l}{ Indeks } & \multicolumn{2}{c}{ Keanekaragam } & Indeks Dominansi Jenis (C) & Indeks Keseragaman Jenis (E) \\
& Jenis H') & & 1 \\
1 & 2,249759 & 0,243738 & 1,126668 \\
2 & 2,183705 & 0,246034 & 1,25 \\
3 & 1,820870 & 0,313095 & \\
\hline
\end{tabular}

Tabel 5 menunjukkan nilai indeks keanekaragaman, indeks dominanansi dan indeks keseragaman pada masing-masing stasiun tidak jauh berbeda. Adanya perbedaan dari nilai-nilai indeks yang diperoleh dalam penelitian ini disebabkan oleh perbedaan jumlah jenis dan jumlah individu/jenis yang berbeda pada masing-masing stasiun. Hal yang sama terjadi pada substrat keramba (pelampung) seperti terlihat pada Tabel 6. 
Madju Siagian : Pengaruh Budidaya Keramba Jaring Apung Terhadap Struktur Komunitas Perifiton pada Substrat yang Berbeda di Sekitar Dam Site Waduk Plta Koto Panjang Kampar Riau

Tabel 6. Nilai Rata-rata Indeks Keanekaragaman Jenis (H'), Dominansi (C) dan Keseragaman Jenis (E) Perifiton pada Substrat Jaring (Pelampung) Setiap Stasiun Selama Penelitian

Table 6. Average Diversity (H'), Dominance (C) and Uniformity Index (E) in cages (floating) Substrate in Koto Panjang Reservoir During Research Period

\begin{tabular}{|c|c|c|c|}
\hline Stasiun & $\begin{array}{ll}\text { Indeks } & \text { Keanekaragam } \\
\text { Jenis H') } & \end{array}$ & Indeks Dominansi Jenis (C) & Indeks Keseragaman Jenis (E) \\
\hline 1 & 1,117586 & 0,471264 & 1,083333 \\
\hline 2 & 1,515897 & 0,363165 & 1,25 \\
\hline 3 & 1,520119 & 0,366229 & 1,333333 \\
\hline
\end{tabular}

Apabila nilai-nilai indeks keanekaragaman, indeks dominansi dan indeks keseragaman pada Tabel 5 dan Tabel 6 dibandingkan terlihat adanya perbedaan nilai-nilai indeks jika substratnya berbeda. Nilai Indeks keanekaragaman jenis pada substrat daun lebih tinggi dibandingkan dengan substrat keramba (pelampung), sebaliknya nilai indeks dominansi pada substrat keramba (pelampung) lebih tinggi dibandingkan dengan substrat daun. Indeks keseragaman pada masing- masing substrat kisarannya tidak jauh berbeda. Nilai indeks keanekaragaman pada substrat daun lebih tinggi dibandingkan dengan yang terdapat pada substrat keramba (pelampung) dan tingginya nilai indeks dominansi pada substrat keramba dibandingkan pada substrat daun disebabkan jumlah jenis dan jumlah individu/jenis pada substrat daun lebih banyak dibandingkan pada substrat keramba sebagaimana terlihat pada Tabel 3.

Berdasarkan nilai rata-rata indeks keanekaragaman jenis perifiton pada setiap stasiun dan substrat yang berbeda selama penelitian pada substrat daun berkisar 1,820872,24975, sedangkan pada substrat jaring (pelampung) berkisar 1,117856-1,520119. Dari data tersebut terlihat bahwa nilai indeks keanekaragaman jenis perifiton pada substrat daun lebih tinggi dibandingkan yang terdapat pada substrat jaring (pelampung). Kondisi ini terjadi karena jumlah jenis dan jumlah individu/jenis yang berbeda-beda sehingga didapatkan nilai indeks keanekaragaman yang berbeda. Hal ini sesuai dengan apa yang dikemukakan oleh Weber (1973), indeks keanekaragaman organisme pada suatu komunitas sangat ditentukan oleh banyaknya jenis dan jumlah individu/jenis.
Berkaitan dengan indeks keanekaragaman ini untuk menentukan kriteria kualitas air William dan Doris (1966) dalam Weber (1973 ) mengatakan. apabila indeks keanekaragaman berkisar 1-3 kriteria kualitas airnya tercemar ringan. Hal yang sama dikemukakan Wiha (1975) dalam Fahrul (2007) yang membuat kriteria kualitas air termasuk tercemar ringan jika indeks keanekaragaman antara 2-3. Apabila indeks keanekaragaman yang diperoleh dari penelitian ini dibandingkan dengan pendapat di atas maka Waduk PLTA Koto Panjang pada zona lakustrin sekitar dam siti kualitas lingkungannya termasuk pada kriteria tercemar ringan. Kualitas lingkungan tercemar ringan ini lebh terlihat pada substrat keramba (pelampung) dibandingkan pada substrat daun. Jadi dari nilai indeks keanekaragaman ini disimpulkan ada dampak aktivitas keramba jaring apung terhadap indeks keanekaragaman perifiton. Hal ini dapat dilihat semakin padat jumlah KJA nilai indeks keanekaragaman semakin menurun. William dan Doris (1966) dalam Weber (1973), mengatakan, jika indeks keanekaragaman antara 1-3, sebaran individu sedang (keragaman sedang), berarti perairan tersebut mengalami tekanan (gangguan) yang sedang atau struktur komunitas organisme yang ada sedang. Indeks keanekaragaman perifiton yang diperoleh dalam penelitian ini berada pada batas kisaran yang dikemukakan di atas, maka dapat dikatakan perairan waduk PLTA Koto Panjang sekitar dam site zona lakustrin telah mengalami tekanan (gangguan) dan struktur komunitas perifiton di waduk tersebut kurang baik atau tercemar ringan. Dalam penelitian ini struktur komunitas yang dilihat pada jaring keramba adalah pada pelampung, untuk itu perlu diamati struktur komunitas perifiton pada substrat jaring kerambanya apa masih baik atau tidak. 
Terjadinya perubahan kualitas linngkungan pada setiap stasiun pada substrat jaring keramba (pelampung) dan substrat daun karena adanya masukan unsur hara dari aktivitas KJA yang menyebabkan perubahan kualitas air.

Indeks dominansi jenis perifiton di sekitar dam site Waduk PLTA Koto Panjang pada masing-masing stasiun dan substrat yang berbeda terendah 0,243738 dan yang tertinggi 0,471264 . Dari indek dominansi jenis dapat dilihat komposisi jenis organisme yang terdapat pada suatu komunitas. Indeks dominansi jenis pada penelitian ini menunjukan pola yang berlawanan dengan indeks keanekaragaman maksudnya apabila indeks keanekaragaman meningkat indeks dominansi menurun atau sebaliknya. Hal ini sesuai dengan pendapat Weber (1973), jika indeks keanekaragaman semakin menurun maka indeks dominansi semakin meningkat. Sehubungan dengan indeks dominansi ini Weber (1973) mengatakan nilainya adalah antara $0-1$, apabila nilainya mendekati $0(<0,5)$ berarti tidak terdapat spesies yang mendominansi spesies lainnya, sebaliknya apabila nilainya mendekati $1 \quad(>0,5)$ berarti terdapat spesies yang mendominasi spesies yang lainnya. Apabila nilai-nilai indeks dominansi yang diperoleh dalam penelitian ini dibandingkan dengan pendapat tersebut yang nilainya mendekati nol, berarti tidak terdapat spesies perifiton yang mendominansi spesies lainnya di sekitar dam site zona lakustrin Waduk PLTA Koto Panjang

Indeks keseragaman atau sering juga disebut dengan indeks kemerataan pada penelitian ini yang terdapat pada Tabel 5 dan Tabel 6 menunnjukkan nilai terendah 1 dan tertinggi 1,8 . Menurut Simpson dalam Odum (1998) nilai indeks keseragaman ini paling tinggi 1 , jadi jika dalam perhitungan diperoleh nilainya lebih dari 1, nilainya tetap 1 . Menurut Bold dan Wynne (1985) dalam Fahrul (2007) nilai indeks keseragaman ini berkisar dari 0-1. Jika indeks keseragaman mendekati $1(>0,5)$ berarti keseragaman organisme dalam suatu perairan berada dalam keadaan seimbang, berarti tidak terjadi persaingan baik terhadap tempat maupun terhadap makanan, sebaliknya jika indeks keseragaman mendekati $0(<0,5)$. Hal yang sama dikemukakan oleh Pilou dalam Krebs (1989). Apabila indeks keseragaman dalam penelitian ini dibandingkan dengan kriteria tersebut maka dapat disimpulkan bahwa keseragaman perifiton di sekitar dam site zona lakustrin Waduk PLTA Koto Panjang berada dalam keadaan seimbang dan tidak terjadi persaingan baik terhadap ruang dan makanan. Hal ini berarti kondisi lingkungan dan parameter fisik- kimiawi yang diamati dalam penelitian ini perairan waduk tersebut sesuai untuk berbagai jenis perifiton.

\section{Simpulan}

Dari hasil penelitian ini disimpulkan bahwa terdapat perbedaan struktur komunitas perifiton di sekitar dam site pada zona lakustrin Waduk PLTA Koto Panjang pada substrat yang berbeda. Berdasarkan nilai indeks keanekaragaman, indeks dominansi dan indeks keseragaman perifiton, perairan di sekitar dam site zona lakustrin Waduk PLTA Koto Panjang telah mengalami tekanan (gangguan) keanekaragaman jenis prifiton kurang baik atau tercemar ringan, tidak ada spesies yang mendominasi dan keseragaman organisme berada dalam keadaan seimbang, tidak terjadi persaingan terhadap makanan dan ruang.

Parameter fisis dan kimia di waduk PLTA Koto Panjang masih dalam ambang batas untuk kehidupan biota dan aktivitas KJA. Aktivitas budidaya ikan dalam KJA mempengaruhi struktur komunitas perifiton pada masing-masing stasiun dan substrat yang berbeda. Jenis dan jumlah individu/jenis perifiton pada substrat daun lebih tinggi dibandingkan pada substrat keramba (pelampung) yang menyebabkan perbedaan pada nilai-nilai indeks keanekaragaman, indeks dominansi dan indeks keseragaman jenis. Parameter kualitas air yang diamati selama penelitian pada masing-masing stasiun masih dapat mendukung hidup dan kehidupan perifiton dan organisme lainnnya.

\section{Ucapan Terima Kasih}

Ucapan terima kasih disampaikan kepada Lembaga Penelitian Universitas Riau yang memberikan dana penelitian yang bersumber dari HIBA DIKTI DIPA tahun anggaran 2015 sehingga penelitian ini dapat dilaksanakan dengan baik. Ucapan terima kasih disampaikan kepada William Silaen, Rudi, Niko dan Sistem 
Madju Siagian : Pengaruh Budidaya Keramba Jaring Apung Terhadap Struktur Komunitas Perifiton pada Substrat yang Berbeda di Sekitar Dam Site Waduk Plta Koto Panjang Kampar Riau

mahasiswa Faperika Univeristas Riau yang membantu pengambilan sampel air di lapangan

\section{Daftar Pustaka}

APHA (American Public Health Association). 1998. Standard Method for The Examination of Water and Wastewater. American Public Health Association. Washingt. D.C.

Boyd, C.E. 1990. Water Quality in Pond for Aquavulture. Birmingham Publishing Company. Birmingham, Alabama.

Cholik, F., Artati dan Arifunddin. 1986. Pengelolaan kualitas Air Kolam Ikan. Dirjen. Perikanan Bekerja Sama dengan Internasional Development Research Center Jakarta.

Fachrul, M. F. 2007. Metode Sampling Bioekologi. PT. Bumi Aksara. Jakarta.

Goldmn, C.R. and A.J. Horme, 1982. Limnology. Mcgraw Hill Internasional Book Company. New York.

Muharram, N. 2006. Struktur Komunitas Perifiton dan Fitoplankton di Bagian Hulu Sungai Ciliwung, Jawa Barat. IPB-Bogor.

Nybakken, 1992. Biologi Laut. Suatu Pendekatan Ekologis. Gramedia. Jakarta.

Nur, M. 2006. Evaluasi Pengelolaan Waduk PLTA Koto Panjang Sebagai Upaya Pelestarian Fungsi Waduk yang Berkelanjutan. IPB. Bogor.

Parker, R. 2002. Aquaculture Science 2 ed. Delmar Thomson Learning. Columbia Circle. Albany.
Pescod, M.B. 1973. Investigation of Rational Effluent and Stream Standards for Tropical Countries. ATT Bangkok.

Pillay, T.V.R. 1992. Aquaculture and The Environment. Fishing News Book. Osney Mead. Oxford. England.

Siagian, M. 2010. Strategi Pengembangan Keramba Jaring Apung Berkelanjutan di Waduk PLTA Koto Panjang, Kampar Riau. Universitas Padjadjaran Bandung.

Siagian, M. 2010. Strategi Pengembangan Keramba Jaring Apung Berkelanjutan di Waduk PLTA Koto Panjang. Jurnal Perikanan dan Kelautan. Fakultas Perikanan dan Ilmu Kelautan Univ. Riau. 15 (2): 145-160.

Siagian, M. 2014. Dampak Keramba Jaring Apung pada Zona Lakustrin Sekitar Dam Site terhadap Kualitas Air Dalam Pengelolaan Waduk PLTA Koto Panjang Kampar Riau

Schmittou, H.R. 1991. Cage Culture. A Method of Fish Production in Indonesia. FRDP. Central Research Institute for Fisheries. Jakarta. Indonesia.

Simarmata, A.H. Siagian. M dan Sihotang, C. 2013. Pengelolaan Waduk Koto Panjang yang Berkelanjutan Berdasarkan Status Trofik dan Beban Perairan. Laporan Penelitian Unggulan Perguruan Tingggi. Lemlit. Univ. Riau Pekanbaru.

Weber, C. I. 1973. Biological Field and Laboratory Metods for Measuring The Quality of Surface Water and Effluents. 